\title{
Nitrogen Fixation by Bacterial Isolates from Decay in Living White Fir Trees [Abies concolor (Gord. and Glend.) Lindl.]
}

\author{
By R. J. SEIDLER \\ Department of Microbiology, Oregon State University, \\ Corvallis, Oregon, 9733I \\ P. E. AHO
}

Forestry Sciences Laboratory, Pacific Northwest Forest and Range Experiment Station, Forest Service, ,U.S.D.A.,', Corvallis, Oregon, 9733 I

P. N. RAJU AND H. J. EVANS

Department of Botany and Plant Pathology, Oregon State University, Corvallis, Oregon, 9733I, U.S.A.

(Received 10 April 1972; revised 15 June 1972)

\section{INTRODUCTION}

Hymenomycetous fungi are reported to be the major cause of decay in living trees (Boyce, I 96I). Invasion and decay by many of these fungi are associated with or follow colonization of wood by bacteria and non-hymenomycetes (Shigo, 1967). During preliminary identification of bacterial isolates from decay in white fir trees, characteristics similar to those of some nitrogen-fixing klebsiellas were observed. Consideration of these observations and the low nitrogen content of wood (Cowling \& Merrill, I966) prompted an examination of these bacteria for $\mathrm{N}_{2}$-fixing capabilities. Twenty-eight per cent of I $45_{5}$ isolates tested exhibited positive nitrogenase activity.

\section{METHODS}

Most cultures used in this study were isolated in 1971 during a study of decay in white fir trees located in nine widely spaced locations in the Rogue River National Forest in southwestern Oregon. Thirty-two isolates were from a similar investigation on this forest in 1969 .

In each of the nine areas, two decay samples were obtained from trees exhibiting an old basal injury or bearing conks of Echinodontium tinctorium Ell. and Ev. or Phellinus pini var. abietis (Karst.) Pilát. The trees were felled and dissected at or near the apparent infection site and near the lower or upper end of the decay column to obtain sample blocks for culturing. The blocks were split and chips from incipient decay, advanced decay and from a discoloured, wet-appearing zone adjacent to the bright wood were aseptically transferred to tubes of malt, malt and yeast extract, potato dextrose and nutrient agars (Difco). Inoculated tubes were incubated at laboratory temperatures until growth was observed and then stored at $2{ }^{\circ} \mathrm{C}$.

Diagnostic tests on pure cultures were performed as recommended in the Clinical Manual of Microbiological Methods (Blair, Lennette \& Truant, 1970) except that incubations were at $30^{\circ} \mathrm{C}$. DNA was extracted and purified from isolates $\mathrm{W}-\mathrm{I}$ and W-3 using conventional techniques (Marmur, 196I; Seidler, Starr \& Mandel, 1969). The guanine-cytosine base 
composition ( $\% \mathrm{GC})$ of duplicate samples were determined by the thermal melting procedure using equation 5 of Mandel, Igambi, Bergendahl, Dodson \& Scheltgen (1970) for calculations. DNA from Escherichia coli $\mathrm{B}$ with a known base composition of $5 \mathrm{I} \% \mathrm{GC}$ was used as a control.

Modified Pankhurst tubes (' $\mathrm{H}$ ' tubes) were utilized in experiments in which acetylene reduction and $\mathrm{N}_{2}$ fixation were investigated (Campbell \& Evans, I969). The major modifications concern the two ' $\mathrm{H}$ ' tube arms $(62 \mathrm{ml}$ total volume) which are identical in size and attached to each other by a connecting tube fitted with a ground glass ball joint and a clamp to facilitate manipulation. One arm of each ' $\mathrm{H}$ ' tube contained $\mathrm{Io} \mathrm{ml}$ of modified Hino and

\section{Table I. Characteristics of bacteria isolated from decay in living white fir trees}

\begin{tabular}{|c|c|c|c|c|}
\hline \multirow{2}{*}{\multicolumn{2}{|c|}{ Source }} & \multicolumn{3}{|c|}{ Isolates $^{\mathrm{a}}$} \\
\hline & & W-I & $w-3$ & $W-I 5$ \\
\hline Locality $^{\mathbf{a}}$ & $\ldots$ & Rye Flat & Rye flat & Cinder pit \\
\hline Tree no. & $\ldots$ & 12 & 15 & 9 \\
\hline Fungal association & $\cdots$ & $\begin{array}{c}\text { Echinodontium } \\
\text { tinctorium }^{\mathrm{b}}\end{array}$ & $\begin{array}{l}\text { Phellinus pini } \\
\text { var. abietis }\end{array}$ & $\begin{array}{c}\text { E. tinctorium and } \\
\text { P. pini var. } \\
\text { abietis }^{\mathrm{c}}\end{array}$ \\
\hline
\end{tabular}

Characteristics

TSI:

Butt
Slant ${ }^{\mathrm{d}}$
MR
VP
Indole
Citrate
Glucose
Lactose
Ornithine decarboxylase
(4 days)
Urease (2 days)
\% GC
Extinction increase during
initial $48 \mathrm{~h}$ of incubation
$\mathrm{C}_{2} \mathrm{H}_{2}$ reduced (nmoles
culture/24 h)

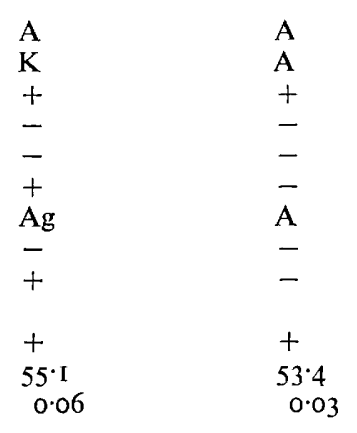

$3151 \quad 645$

$$
\begin{gathered}
\mathrm{A} \\
\mathrm{K} \\
+ \\
- \\
- \\
+ \\
\mathrm{Ag} \\
- \\
\pm \\
- \\
\text { N.D. } \\
\text { O.10 } \\
5908
\end{gathered}
$$

a These isolates collected from Ashland Ranger District.

b From discoloured wet-appearing zone between incipient decay and bright wood.

c Incipient decay.

¿ Acid (A) or alkaline (K) reaction.

e Gas produced $(\mathrm{g})$.

f All isolates failed to produce acid from sucrose and maltose, all were Gram-negative, rods, $\mathrm{H}_{2} \mathrm{~S}$ negative, oxidase negative, gelatinase negative, and arginine and lysine decarboxylase negative; all fermented mannitol and fructose, were catalase positive and weakly motile at room temperature; maximum growth temperature about $35^{\circ} \mathrm{C}$.

$\mathrm{g}$ Exposed to acetylene for $24 \mathrm{~h}$ after initial $48 \mathrm{~h}$ incubation.

Wilson medium (Hino \& Wilson, 1958$)\left(50 \mathrm{mg} \mathrm{CaCl}{ }_{2} \cdot 2 \mathrm{H}_{2} \mathrm{O} / 1\right.$ of medium instead of $\mathrm{CaCO}_{3}$ and $2 \%$ mannitol instead of sucrose). The procedure for sterilization, inoculation, flushing with $\mathrm{N}_{2}$, maintenance of anaerobic conditions and sampling have been described (Campbell \& Evans, 1969). Ethylene in each sample was assayed by using an Aerograph model 600D gas chromatograph fitted with a Porapak $\mathrm{R}$ column and flame ionization detector. 
RESULTS

One hundred and forty-five cultures ( 113 from the I97I study and 32 from 1969 ) representing six different fungal associations from 44 trees in 26 localities were tested for acetylenereducing capability. Forty isolates from 21 trees in 14 different areas reduced acetylene at rapid rates when cultured anaerobically. When more than two successive transfers were made to a 'nitrogen-free medium', consistent growth occurred only with isolates that reduced acetylene. Of 80 isolates tested, none reduced acetylene when cultured aerobically. Fifteen bacterial cultures which reduced acetylene were isolated from decays associated with Phellinus pini var. abietis, Io each with E. tinctorium and Pholiota adiposa (Fr.) Kumm, and four with Hericium abietis (Weir ex Hubert) K. Harrison. Forty-three percent of the $\mathrm{N}_{2}$-fixing isolates were from the discoloured, wet-appearing zone between incipient decay and bright wood, $45 \%$ from the incipient zone and only $12 \%$ from advanced decay.

Properties of three representative acetylene reducing isolates (W-I, W-3, and W-I5) are presented in Table I. After incubation in $\mathrm{H}$ tubes for $24 \mathrm{~h}$ ten $\mathrm{ml}$ cultures reduced acetylene to ethylene at rates ranging from 645 to $5908 \mathrm{nmol}$ in $24 \mathrm{~h}$. These rates were comparable to those for the other 37 positive isolates. Tubes inoculated with all isolates lacking nitrogenfixing capabilities and control tubes inoculated with sterile water produced less than $2 \mathrm{nmol}$ of ethylene under comparable conditions. Nitrogen analyses of a series of cultures of W-I showed that each $\mathrm{I} 0 \mathrm{ml}$ culture fixed about $4 \mu \mathrm{mol}$ of $\mathrm{N}_{2}$ during a growth period of $90 \mathrm{~h}$. Acetylene-reducing activity of W-I also proceeded at a rapid rate during growth over $96 \mathrm{~h}$ although the presence of acetylene in the culture for $25 \mathrm{~h}$ inhibited growth as expected.

From reactions on Triple Sugar Iron agar (TSI), methyl red-Voges Proskauer (MRVP) tests, \% GC content, and the $\mathrm{N}_{2}$-fixing capability, these three isolates seem similar to the Klebsiella group (Blair et al. 1970; Edwards \& Ewing, 1962). However, these cultures are atypical of the Klebsiella group in that they do not grow at $37^{\circ} \mathrm{C}$, do not ferment lactose, sucrose, and maltose, and two out of three showed no active decarboxylase activities. Culture W-I however is ornithine positive. Nitrogen-fixing enterics have been isolated from plants and soil (Line \& Loutit, I97I ; Evans, Campbell \& Hill, 1972) which, because of their typical biochemical properties, could be assigned to the genera Klebsiella or Enterobacter. The maximum growth temperature, decarboxylase reactions and MRVP tests reported for an atypical $\mathrm{N}_{2}$-fixing bacterium described as Escherichia intermedia (Line \& Loutit, 1971) are similar to those of our isolates. Differences exist, however, in the urease reaction and capacity to ferment lactose and sucrose. There are no previous descriptions of such biochemically deficient klebsiellas and hence there is no justification for classifying our isolates into any known species of Klebsiella or Enterobacter.

In view of the unique phenotypic properties of our isolates and the present status of the systematics of the nitrogen-fixing enterics, we feel it would be premature to make specific nomenclatorial recommendations.

To our knowledge this is the first report of nitrogen-fixing bacteria in decays in living trees. The possible role of these bacteria in the ecology of the decay process is obvious and is being investigated further.

The purification and taxonomical studies were supported by a co-operative aid agreement between RJS and USDA Forest Service, Pacific Northwest Forest and Range Experiment Station. Funds from the Oregon State Research Council to RJS for general laboratory operation are acknowledged. The nitrogen fixation experimentation was supported in part by NSF grant GB29600X. A UNESCO Fellowship to PNR, Centre of Advanced Study in 
Botany, University of Madras, India is gratefully acknowledged. The contribution of PEA is in part from a Ph.D. thesis to be submitted to the Department of Botany and Plant Pathology, Oregon State University.

\section{REFERENCES}

Blair, J. E., Lennette, E. H. \& Truant, J. P. (1970). Manual of Clinical Microbiology, p. 727. Baltimore: Williams \& Wilkins.

Boyce, J. S. (1961). Forest Paihology, p. 572. New York: McGraw-Hill.

CAMPBell, N. E. R. \& Evans, H. J. (I969). Use of Pankhurst tubes to assay acetylene reduction by facultative and anaerobic nitrogen-fixing bacteria. Canadian Journal of Microbiology 15, 1342-1 343.

Cowling, E. B. \& Merrill, W. (1966). Nitrogen in wood and its role in wood deterioration. Canadian Journal of Botany 44, 1539-1 554 .

Edwards, P. R. \& EwING, W. H. (1962). Identification of Enterobacteriaceae, p. 258. Minneapolis, Minnesota: Burgess Publishing Company.

Evans, H. J., Campbell, N. E. R. \& Hill, S. (1972). Asymbiotic nitrogen-fixing bacteria from the surfaces of nodules and roots of legumes. Canadian Journal of Microbiology 18, 13-21.

Hino, S. \& Wilson, P. W. (1958). Nitrogen fixation by a facultative bacillus. Journal of Bacteriology 75 , 403-408.

LiNE, M. A. \& LoutiT, M. W. (I97I). Non-symbiotic nitrogen-fixing organisms from some New Zealand Tussock-grassland soils. Journal of General Microbiology 66, 309-318.

Mandel, M., Igambi, L., Bergendahl, J., Dodson, M. J., Jun. \& Scheltgen, E. (1970). Correlation of melting temperature and cesium chloride buoyant density of bacterial deoxyribonucleic acid. Journal of Bacteriology ro1, 333-338.

Marmur, J. (1961). A procedure for the isolation of DNA from microorganisms. Journal of Molecular Biology 3, 208-2 18 .

Seidler, R. J., Starr, M. P. \& Mandel, M. (1969). Deoxyribonucleic acid characterization of bdellovibrios. Journal of Bacteriology 100, 786-790.

SHIGo, A. L. (1967). Successions of organisms in discoloration and decay of wood. In International Review of Forest Research, vol. 2, pp. 237-299. New York: Academic Press. 